\title{
Role of cytochrome P450 genotype in the steps toward personalized drug therapy
}

\author{
This article was published in the following Dove Press journal: \\ Pharmacogenomics and Personalized Medicine \\ 4 November 2011 \\ Number of times this article has been viewed
}

\section{Larisa H Cavallari ${ }^{1,2}$ \\ Hyunyoung Jeong ${ }^{1,2}$ \\ Adam Bress'}

'Department of Pharmacy Practice, ${ }^{2}$ Department of Biopharmaceutical Sciences, College of Pharmacy, University of Illinois at Chicago, Chicago, IL, USA
Correspondence: Larisa H Cavallari Department of Pharmacy Practice, University of Illinois at Chicago College of Pharmacy, 833 S Wood St, Room 164, Chicago, IL 606I2-7230, USA

Tel +l 3 I 29960886

$\mathrm{Fax}+\mathrm{I} 3129960379$

Email humma@uic.edu
Abstract: Genetic polymorphism for cytochrome 450 (P450) enzymes leads to interindividual variability in the plasma concentrations of many drugs. In some cases, $P 450$ genotype results in decreased enzyme activity and an increased risk for adverse drug effects. For example, individuals with the CYP2D6 loss-of-function genotype are at increased risk for ventricular arrhythmia if treated with usual does of thioridazine. In other cases, $P 450$ genotype may influence the dose of a drug required to achieve a desired effect. This is the case with warfarin, with lower doses often necessary in carriers of a variant $C Y P 2 C 9 * 2$ or $* 3$ allele to avoid supratherapeutic anticoagulation. When a prodrug, such as clopidogrel or codeine, must undergo hepatic biotransformation to its active form, a loss-of-function P450 genotype leads to reduced concentrations of the active drug and decreased drug efficacy. In contrast, patients with multiple CYP2D6 gene copies are at risk for opioid-related toxicity if treated with usual doses of codeine-containing analgesics. At least 25 drugs contain information in their US Food and Drug Administration-approved labeling regarding $P 450$ genotype. The CYP2C9, CYP2C19, and CYP2D6 genes are the P450 genes most often cited. To date, integration of $P 450$ genetic information into clinical decision making is limited. However, some institutions are beginning to embrace routine $P 450$ genotyping to assist in the treatment of their patients. Genotyping for $P 450$ variants may carry less risk for discrimination compared with genotyping for disease-associated variants. As such, P450 genotyping is likely to lead the way in the clinical implementation of pharmacogenomics. This review discusses variability in the CYP2C9, CYP2C19, and CYP2D6 genes and the implications of this for drug efficacy and safety.

Keywords: cytochrome P450, polymorphism, allele, drug metabolism, genotype

\section{Introduction}

It is well recognized that variation in the genes for cytochrome P450 (P450) enzymes contributes to interindividual differences in the plasma concentrations of drug substrates, resulting in interpatient variability in drug efficacy and safety. Functional polymorphism has been discovered for CYP2A6, CYP1A2, CYP2C9, CYP2C19, $C Y P 2 D 6$, and $C Y P 3 A 4 / 5$. At least 25 drugs now contain pharmacogenetic information related to P450 enzymes in their US Food and Drug Administration-approved labeling. ${ }^{1}$ Examples of such drugs are provided in Table 1. The P450 genes included in drug labeling are limited to $C Y P 2 C 9, C Y P 2 C 19$, and CYP2D6. Thus, this review will focus on genetic variation for the CYP2C9, CYP2C19, and CYP2D6 enzymes and drug substrates for these enzymes. 
Table I Examples of drugs with genotype information included in their US Food and Drug Administration-approved labeling'

\begin{tabular}{|c|c|c|}
\hline Drug & Biomarker & Clinical implication \\
\hline \multicolumn{3}{|c|}{ Antidepressants, anxiolytics, and antipsychotics } \\
\hline Aripiprazole & CYP2D6 & Increased drug exposure in CYP2D6 PMs; dose reduction is recommended \\
\hline Atomoxetine & CYP2D6 & $\begin{array}{l}\text { Increased plasma concentrations in CYP2D6 PMs, which may increase the risk for } \\
\text { adverse effects; dose adjustment is recommended }\end{array}$ \\
\hline Clozapine & CYP2D6 & $\begin{array}{l}\text { Increased plasma concentrations possible in CYP2D6 PMs; clinical significance is } \\
\text { unclear }{ }^{121}\end{array}$ \\
\hline Diazepam & CYP2C19 & Decreased enzyme activity may lead to increased sedation \\
\hline Doxepine & CYP2D6 & Increased plasma concentrations in CYP2D6 PMs; lower doses may be needed \\
\hline Fluoxetine & CYP2D6 & Increased plasma concentration of S-fluoxetine in PMs; clinical significance is unclear ${ }^{119}$ \\
\hline Protriptyline & CYP2D6 & Increased plasma concentrations in CYP2D6 PMs; lower doses may be needed \\
\hline Risperidone & CYP2D6 & Increased plasma concentrations in CYP2D6 PMs; clinical significance is unclear ${ }^{121}$ \\
\hline Thioridazine & CYP2D6 & $\begin{array}{l}\text { Increased plasma concentrations in CYP2D6 PMs, which increases the risk for } \\
\text { drug-induced QT-interval prolongation and arrhythmias. }{ }^{24} \text { Thioridazine is } \\
\text { contraindicated in CYP2D6 PMs }\end{array}$ \\
\hline Venlafaxine & CYP2D6 & $\begin{array}{l}\text { Increased plasma concentrations in CYP2D6 PMs; may increase the risk for } \\
\text { adverse drug effects }\end{array}$ \\
\hline \multicolumn{3}{|c|}{ Analgesic drugs } \\
\hline Celecoxib & CYP2C9 & $\begin{array}{l}\text { Increased drug exposure with CYP2C9 reduced function alleles; use celecoxib } \\
\text { with caution. Consider dose reduction in patients with the } * 3 / * 3 \text { genotype }\end{array}$ \\
\hline Codeine & CYP2D6 & Decreased morphine plasma levels and analgesic effects in CYP2D6 PMs ${ }^{106-109}$ \\
\hline Tramadol & CYP2D6 & Decreased O-desmethyltramado plasma levels and analgesic effects in CYP2D6 PMs s $^{106-109}$ \\
\hline \multicolumn{3}{|c|}{ Cardiovascular drugs } \\
\hline Carvedilol & CYP2D6 & $\begin{array}{l}\text { Increased plasma levels of } R \text {-carvedilol in CYP2D6 PMs; potential increased risk for } \\
\text { adverse effects, such as dizziness }\end{array}$ \\
\hline Clopidogrel & CYP2C19 & $\begin{array}{l}\text { Decreased antiplatelet effects in CYP2C19 PMs; may increase risk for adverse } \\
\text { cardiovascular events, including stent thrombosis }{ }^{68,77}\end{array}$ \\
\hline Metoprolol & CYP2D6 & Increased plasma levels in CYP2D6 PMs; clinical significance is unclear ${ }^{125,126}$ \\
\hline Propafenone & CYP2D6 & Increased plasma levels in CYP2D6 PMs; clinical significance is unclear \\
\hline Propranolol & CYP2D6 & Increased plasma levels in CYP2D6 PMs; clinical significance is unclear ${ }^{125,126}$ \\
\hline Warfarin & CYP2C9 & $\begin{array}{l}\text { Reduced S-warfarin clearance with a CYP2C9 reduced function allele; need for lower } \\
\text { dose requirements; increased bleeding risk } \text { ri,22,24,33 }^{2}\end{array}$ \\
\hline \multicolumn{3}{|c|}{ Proton pump inhibitors } \\
\hline Omeprazole & CYP2C19 & Potentially lower efficacy in CYP2CI 9 EMs compared to $\mathrm{PMs}^{92}$ \\
\hline Rabeprazole & CYP2C19 & Potentially lower efficacy in CYP2CI 9 EMs compared to $\mathrm{PMs}^{93}$ \\
\hline \multicolumn{3}{|l|}{ Other drugs } \\
\hline Cevimeline & CYP2D6 & $\begin{array}{l}\text { Increased plasma levels in CYP2D6 PMs; may increase risk for adverse effects; use } \\
\text { with caution in patients with known or suspected deficiency in CYP2D6 activity }\end{array}$ \\
\hline Nelfinavir & CYP2C19 & $\begin{array}{l}\text { Increased nelfinavir plasma levels with reduced-function } \mathrm{CYP} 2 \mathrm{CI} 9 \text { alleles; may reduce } \\
\text { risk for virologic failure }{ }^{99}\end{array}$ \\
\hline Tetrabenazine & CYP2D6 & $\begin{array}{l}\text { Increased plasma concentrations of the primary drug metabolites of tetrabenazine are } \\
\text { expected in PMs compared to EMs, leading to an increased risk for adverse effects. } \\
\text { Patients needing doses above } 50 \mathrm{mg} / \text { day should be genotyped for CYP2D6 variants. } \\
\text { The maximum recommended dose if } 50 \mathrm{mg} / \text { day, with no more than } 25 \mathrm{mg} \text { administered } \\
\text { in a single dose for PMs. The maximum recommended dose in EMs and IMs is } \\
100 \mathrm{mg} / \text { day, with no more than } 37.5 \mathrm{mg} \text { per dose }\end{array}$ \\
\hline Tolterodine & CYP2D6 & Increased plasma concentrations in CYP2D6 PMs; clinical significance is unclear \\
\hline
\end{tabular}

Abbreviations: PM, poor metabolizer; EM, extensive metabolizer; IM, intermediate metabolizer.

\section{CYP2C9 genotype}

\section{Functionality of CYP2C9 variants}

The CYP2C9 enzyme metabolizes approximately $15 \%$ of clinically used drugs, including some anticoagulants (eg, $S$-warfarin), hypoglycemics (eg, tolbutamide), angiotensin II receptor blockers (eg, losartan), antiepileptics (eg, phenytoin), and nonsteroidal anti-inflammatory drugs (eg, diclofenac). ${ }^{2}$ To date, 35 variants of the $C Y P 2 C 9$ gene have been identified. ${ }^{3}$ There are racial differences in the frequency of CYP2C9 variants, as shown in Table 2. ${ }^{4-6}$ The CYP $2 C 9^{*} 2$ allele is common in Caucasians and results from the R144C substitution located on the exterior surface of the enzyme. ${ }^{7}$ This allele leads to decreased CYP2C9 enzyme activity in vitro, the magnitude of which ranges from $8 \%$ to 
Table 2 CYP2C9 allele frequencies by race ${ }^{4-6}$

\begin{tabular}{llll}
\hline $\begin{array}{l}\text { CYP2C9 } \\
\text { allele }\end{array}$ & Caucasians & African Americans & Asians \\
\hline$* 2$ & $0.13-0.14$ & 0.02 & $<0.01$ \\
$* 3$ & $0.06-0.11$ & 0.01 & 0.02 \\
$* 5$ & $<0.01$ & 0.01 & $<0.01$ \\
$* 6$ & $<0.01$ & 0.01 & $<0.01$ \\
$* 8$ & $<0.01$ & 0.06 & $<0.01$ \\
$* 11$ & $<0.01$ & $0.02-0.04$ & $<0.01$ \\
\hline
\end{tabular}

94\% depending on the CYP2C9 substrate (reviewed in Lee et $\mathrm{al}^{8}$ ). The $C Y P 2 C 9 * 3$ allele is also common in Caucasians and results from the $1359 \mathrm{~L}$ substitution at the substrate recognition site of the enzyme. ${ }^{9}$ This leads to a $71 \%-96 \%$ decrease in enzyme activity (also reviewed in Lee et $\mathrm{al}^{8}$ ). The decreased catalytic activities of $C Y P 2 C 9 * 2$ and $* 3$ are in part due to enhanced uncoupling (ie, abortive catalytic cycle) of the reaction or a disruption of the water network in the variant enzymes. ${ }^{10}$ The $C Y P 2 C 9 * 5, * 6$, *8, and $* 11$ alleles predominate in African populations, with decreased enzyme activity reported with the $* 5$, $* 6$, and $* 11$ alleles. ${ }^{11-13}$ The $C Y P 2 C 9 * 8$ allele is the most common of these alleles in African Americans and results from the R150H substitution in exon 3. Data on the effects of the CYP2C $9 * 8$ allele on enzyme activity are inconsistent. Although an in vitro study showed increased tolbutamide metabolism with the CYP $2 C 9 * 8$ variant compared with the wild type, ${ }^{13}$ in vivo studies using phenytoin or losartan revealed decreased or no change in drug elimination in $C Y P 2 C 9 * 8$ carriers. ${ }^{12,14}$ This discrepancy may reflect substrate-specific effects of $C Y P 2 C 9$ variants on enzyme activity, as has been previously reported for the $C Y P 2 C 9 * 2$ and $* 3$ alleles, ${ }^{8,15}$ the underlying molecular mechanisms for which remain to be characterized.

\section{Impact of CYP2C9 genotype on warfarin response}

Warfarin is the most commonly prescribed oral agent for the prevention of thromboembolism. Warfarin has a narrow therapeutic index and is dosed according to the international normalized ratio (INR), with an INR of two to three recommended for most indications. ${ }^{16}$ The risk for thrombosis increases with subtherapeutic anticoagulation, ${ }^{17,18}$ while the risk for bleeding increases significantly when the INR exceeds four. ${ }^{19}$ Warfarin is a challenging drug to manage, largely because the dose required to achieve a therapeutic INR varies as much as 20 -fold among individuals. ${ }^{20}$

Warfarin is a racemic mixture, and the more potent $S$-enantiomer is metabolized almost exclusively by CYP2C9 to the inactive 7-hydroxy metabolite. The clearance of $S$-warfarin is reduced approximately $40 \%$ with the CYP $2 C 9 * 1 / 22$ genotype, up to $75 \%$ with the $* 1 / * 3$ genotype, and by as much as $90 \%$ with the $* 3 / * 3$ genotype. ${ }^{21,22}$ Accordingly, lower warfarin doses are generally required in the presence of a $C Y P 2 C 9 * 2$ or $* 3$ allele. ${ }^{4,5,20,23-26}$ For example, Taube et $\mathrm{al}^{27}$ reported that patients with a variant CYP $2 C 9 * 2$ or $* 3$ allele required between $61 \%$ and $86 \%$ of the dose needed by $* 1$ allele homozygotes.

Table 3 shows warfarin dose requirements by CYP2C 9 genotype across racial groups according to data from the International Warfarin Pharmacogenetics Consortium, a collaboration of 21 research groups from four continents who have pooled genotype and phenotype data from over 5700 warfarin-treated patients. ${ }^{28,29}$ As shown, CYP2C9 genotype influences warfarin dose requirements across racial groups. In genome-wide association studies in Caucasians, the CYP $2 C 9^{*} 2$ and $* 3$ alleles were shown to explain $9 \%-12 \%$ of the total variability in warfarin dose requirements. ${ }^{30,31}$

African Americans are underrepresented in warfarin pharmacogenomic studies. However, recent data show significantly lower warfarin dose requirements among patients with a $C Y P 2 C 9 * 5, * 6, * 8$, or $* 11$ allele compared to those with the $* 1 / * 1$ genotype. ${ }^{5}$ Specifically, among 226 African Americans, the warfarin maintenance dose was $18 \%$ lower in individuals with a $C Y P 2 C 9 * 5, * 6, * 8$, or $* 11$ allele compared to those with the $* 1 / * 1$ genotype (median dose of $5.0 \mathrm{mg}$ /day versus $6.1 \mathrm{mg} /$ day, $P=0.004)$. The $C Y P 2 C 9$ genotype explained approximately $8 \%$ of the total variance in warfarin dose, just slightly less than that in Caucasians. In a recent targeted resequencing approach, Perera et $\mathrm{al}^{32}$ found a novel CYP2C9 single nucleotide polymorphism in the African American genome that was associated with higher warfarin dose requirements. The $18786 \mathrm{~A}>\mathrm{T}$ single nucleotide polymorphism is located in intron three and occurs in $40 \%$ of African Americans. In a cohort of over 300 African

Table 3 Median warfarin dose requirements by CYP2C9 genotype across racial groups, according to the data from the International Warfarin Pharmacogenetics Consortium ${ }^{29}$

\begin{tabular}{llll}
\hline CYP2C9 & \multicolumn{3}{l}{ Warfarin dose requirements $(\mathbf{m g} /$ day $)$} \\
\cline { 2 - 4 } genotype & $\begin{array}{l}\text { Caucasians } \\
(\mathbf{n}=\mathbf{3 0 6 2})\end{array}$ & $\begin{array}{l}\text { African Americans } \\
(\mathbf{n}=\mathbf{6 4 5})\end{array}$ & $\begin{array}{l}\text { Asian } \\
(\mathbf{n}=1 \mathbf{0 6 3})\end{array}$ \\
\hline$* I / * I$ & 5.0 & 5.7 & 3.2 \\
$* I / * 2$ & 4.0 & 5.4 & - \\
$* I / * 3$ & 3.4 & 5.0 & 2.3 \\
$* 2 / * 2$ & 3.3 & - & - \\
$* 2 / * 3$ & 2.2 & - & - \\
$* 3 / * 3$ & 1.1 & - & 2.0 \\
\hline
\end{tabular}

Note: The *2 allele is rare in Asians, and the homozygous variant genotype is rare in African Americans. 
Americans, investigators observed a $3.7 \mathrm{mg} /$ week increase in warfarin dose requirements for each $18786 \mathrm{~T}$ allele.

The CYP2C9 genotype has also been implicated as a risk factor for over-anticoagulation and bleeding with warfarin. ${ }^{23,24,26,33}$ Limdi et $\mathrm{al}^{33}$ conducted one of the largest studies to examine bleeding risk according to $C Y P 2 C 9$ genotype. Among 446 patients started on warfarin, including 227 African Americans, investigators observed 44 major bleeding events during a 2-year follow-up period. The variant CYP2C9*2, *3, *5, *6, and *11 alleles conferred an increased risk of major bleeding, with an adjusted hazard ratio of 3.0 (95\% confidence interval of 1.2-7.5). The bleeding risk was similar between Caucasians and African Americans. Interestingly, while the association between $C Y P 2 C 9$ genotype and risk for bleeding was highest during warfarin initiation, it persisted after dose stabilization. These data suggest that bleeding should be closely monitored throughout warfarin therapy for patients with a variant $C Y P 2 C 9$ allele. Based on the totality of data, $C Y P 2 C 9$ variants appear to increase the bleeding risk with warfarin approximately twofold. ${ }^{34}$

There are data suggesting that $C Y P 2 C 9$ gene expression changes during development, and this, in turn, may lead to age-related differences in the $C Y P 2 C 9$ genotype-drug response phenotype. ${ }^{35}$ In support of differential genotype effects by age, a recent study showed minimal influence of CYP2C9 genotype on warfarin dose variability in pediatric patients. ${ }^{36}$ Specifically, among 59 children (aged $1-19$ years) treated with either warfarin or the vitamin $\mathrm{K}$ antagonist phenprocoumon, CYP2C9 genotype explained $<1 \%$ of the variability in vitamin $\mathrm{K}$ antagonist dose. Age was the most important predictor of dose requirement, explaining $28 \%$ of variance in dose.

Two small prospective trials and a comparative effectiveness study provide evidence of clinical benefit with genotype-guided warfarin dosing in adult populations. ${ }^{37-39}$ Caraco et $\mathrm{al}^{37}$ randomized 191 patients to warfarin dosing based on either clinical factors plus CYP2C9 genotype or clinical factors alone. Genotype-guided dosing resulted in more rapid attainment of stable anticoagulation, more time spent within the therapeutic range, and a lower incidence of minor bleeding than dosing according to clinical factors alone. Similarly, Huang et $\mathrm{al}^{39}$ reported that dosing based on genotypes for $C Y P 2 C 9$ and vitamin $\mathrm{K}$ epoxide reductase complex 1 (VKORC1), which codes for the primary target of warfarin, improved the time to achieve stable dosing in a small Asian population.

Epstein et $\mathrm{al}^{38}$ evaluated the effect of $C Y P 2 C 9$ and $V K O R C 1$ genotyping at the time of warfarin initiation on clinical outcomes. In this comparative effectiveness study, the incidence of hospitalization was compared between a group of 896 patients offered free genotyping and a control group of nearly 2700 patients who started warfarin the previous year and were not offered genotyping. Genotype results were provided to each patient's physician with an interpretative report. Those who underwent genotyping had fewer hospitalizations for any cause and fewer hospitalizations for bleeding or thromboembolism during the 6-month follow-up period compared with controls.

Findings from these positive studies are tempered by findings from two small $(n=206-230)$ prospective trials of Caucasians showing no benefit with genotype-guided warfarin dosing in terms of time spent in the therapeutic INR range during the initial months of therapy. ${ }^{40,41}$ Several large multicenter randomized-controlled clinical trials are underway to further assess the clinical utility of warfarin pharmacogenetics. One of the largest of these is the National Heart, Lung, and Blood Institute-sponsored Clarification of Optimal Anticoagulation Through Genetics trial. ${ }^{42}$ This trial is targeting an enrollment of 1238 patients randomized to either a genotype-guided or clinical warfarin-dosing strategy. The study will assess the primary outcome of percent of time spent within the therapeutic range and is expected to be completed in early 2012 .

In 2007, warfarin labeling was revised to include pharmacogenetic data. The label was further revised in 2010 to include a dosing table based on CYP2C9 and VKORC1 genotypes. ${ }^{43}$ At least four US Food and Drug Administrationcleared genotyping assays are available for clinical use. There are also a number of published algorithms to assist clinicians with warfarin dosing when $C Y P 2 C 9$ genotype is known. ${ }^{28,44} 46$ However, a limitation of most genotyping assays and algorithms is that they do not include $C Y P 2 C 9$ variants that are common in African Americans and thus may have lower utility in this population. Many clinicians and third-party payers are awaiting results of ongoing clinical trials before embracing genotype-guided warfarin dosing.

\section{CYP2C1 9 genotype}

\section{Functionality of CYP2CI 9 variants}

The CYP2C19 enzyme metabolizes approximately 10\% of clinically used drugs, including $S$-mephenytoin, proton pump inhibitors (PPIs), and nelfinavir. The CYP2C19 enzyme is also responsible for biotransformation of clopidogrel to its pharmacologically active form. Genetic deficiency in CYP2C19-mediated $S$-mephenytoin elimination was first reported in $1979,{ }^{47}$ with the urinary excretion rate of 
4-hydroxymephenytoin (a metabolite of $S$-mephenytoin produced by CYP2C19 $)^{48}$ used to discriminate extensive metabolizers (EMs; possessing normal enzyme activity) from poor metabolizers (PMs; with reduced or absent enzyme activity) for CYP2C19 substrates. ${ }^{49,50}$

To date, 28 CYP2C19 variants have been identified. ${ }^{51}$ The CYP2C19*1 allele is considered the wild-type allele, with normal enzyme activity. The $C Y P 2 C 19 * 2$ allele is the primary allele responsible for the PM phenotype in Asians and Caucasians. ${ }^{52}$ Other, less common, defective alleles leading to the PM phenotype include CYP2C19*3 in Asians ${ }^{53}$ and CYP2C19*4, *5, *6, *7, and *8 in Caucasians. ${ }^{54}$ The CYP2C19*2 through $* 8$ alleles are deemed loss-of-function alleles. Both CYP2C19*2 (c.681G $>\mathrm{A})$ and $* 3($ c.636G $>\mathrm{A})$ produce a truncated nonfunctional protein. The $C Y P 2 C 19 * 2$ allele results from a splicing defect in exon 5, while the CYP 2C19*3 allele results from a single base substitution leading to a premature stop codon in exon $4 .{ }^{52}$ Various basepair sequence changes in the CYP 2 C19*4, *5, *6, *7, and $* 8$ alleles negatively influence expression of the protein and catalytic activity. ${ }^{55}$ However, the $C Y P 2 C 19 * 17$ allele results from polymorphisms in the gene promoter region (c.99C $>\mathrm{T}$ and c. $991 \mathrm{~A}>\mathrm{G}$ ) and increases enzyme activity due to enhanced gene transcription. Thus, CYP2C19*17 is deemed a gain-of-function allele. ${ }^{56} C Y P 2 C 19$ genotype confers four phenotypes: extensive metabolism $(* 1 / * 1)$, poor metabo$\operatorname{lism}(\mathrm{eg}, * 2 / * 2$, $* 2 / * 3$, or $* 3 / * 3)$, intermediate metabolism (eg, $* 1 / * 2$,), and ultrarapid metabolism $(* 1 / * 17, * 17 / * 17)$. There are marked racial differences in the frequencies of CYP2C19 phenotypes, as shown in Table 4, with Asians having the highest frequencies of the PM and intermediate metabolizer (IM) phenotypes. ${ }^{57,58}$

\section{Impact of CYP2C19 genotype on clopidogrel effectiveness}

Clopidogrel is an antiplatelet agent that is widely used in patients with cardiovascular disease. Clopidogrel, in combination with aspirin, has been shown to reduce morbidity and mortality in patients with an acute coronary syndrome

Table 4 The frequency of CYP2C19 phenotypes by race res, $^{53,58}$

\begin{tabular}{llll}
\hline Race & \multicolumn{2}{l}{ CYP2C19 phenotype } \\
\cline { 2 - 4 } & PMs & IMs & UMs \\
\hline Caucasian & $1 \%-7 \%$ & $25 \%$ & $40 \%$ \\
Asian & $13 \%-23 \%$ & $50 \%$ & $<5 \%$ \\
African American & $1 \%-7 \%$ & $30 \%$ & $45 \%$ \\
\hline
\end{tabular}

Note: Patients without the PM, IM, or UM phenotype are presumably EMs.

Abbreviations: PMs, poor metabolizers; IMs, intermediate metabolizers; UMs, ultrarapid metabolizers.
(ACS) who are either managed medically or with coronary revascularization. ${ }^{59-61}$ Dual antiplatelet therapy with clopidogrel plus aspirin also reduces the risk for coronary stent thrombosis following percutaneous coronary intervention (PCI). ${ }^{62}$ There is marked interpatient variability in clopidogrel's effectiveness, with approximately $25 \%$ of treated patients exhibiting residual ex vivo platelet aggregation. ${ }^{63}$ These patients are at increased risk for major adverse cardiac events, including myocardial infarction and stent thrombosis. ${ }^{64}$ The variability in clopidogrel response is largely attributed to interpatient differences in clopidogrel pharmacokinetics.

Clopidogrel requires hepatic bioactivation to its active thiol metabolite, which irreversibly binds to the platelet $\mathrm{P} 2 \mathrm{Y}_{12}$ receptor, thus inhibiting platelet activation and subsequent aggregation. Approximately $85 \%$ of the oral dose is inactivated by esterases, leaving only $15 \%$ available for hepatic bioactivation to the active metabolite. Bioactivation of clopidogrel is a two-step oxidative process, as shown in Figure 1. The CYP2C19 enzyme is involved in both oxidative steps. Reduced or absent CYP2C19 activity, secondary to either genetic polymorphism or interacting medication (eg, PPIs) results in decreased exposure to the active thiol metabolite, which, in turn, diminishes clopidogrel's effectiveness.

IMs and PMs produce approximately 30\%-50\% less of the active clopidogrel metabolite compared with EMs. ${ }^{65-68}$ As a result, IMs and PMs may derive less protection from thrombotic events with clopidogrel. Genetic substudies of a number of large clinical trials have demonstrated a higher incidence of stent thrombosis and major adverse cardiovascular events (ie, cardiovascular death, myocardial infarction, or stroke) following ACS or PCI among clopidogrel-treated patients with the PM or IM phenotype compared with similarly treated EMs. ${ }^{68-76}$

Mega et $\mathrm{al}^{77}$ conducted a meta-analysis of nine clinical trials including 9685 patients, of whom 54\% had ACS and 91\% underwent PCI. The hazard ratio for major adverse cardiovascular events was 1.55 (95\% confidence interval 1.11-2.17) in carriers of one loss-of-function allele (IMs) and 1.76 (95\% confidence interval 1.24-2.50) for carriers of two loss-of-function alleles (PMs), compared with noncarriers. Among patients who underwent PCI with stent placement, the hazard ratio for stent thrombosis was 2.67 (95\% confidence interval 1.69-4.22) and 3.97 (95\% confidence interval 1.75-9.02) in carriers of one or two loss-of-function alleles, respectively, compared with noncarriers.

In contrast, a substudy of two large placebo-controlled trials showed no effect of CYP2C19 loss-of-function 


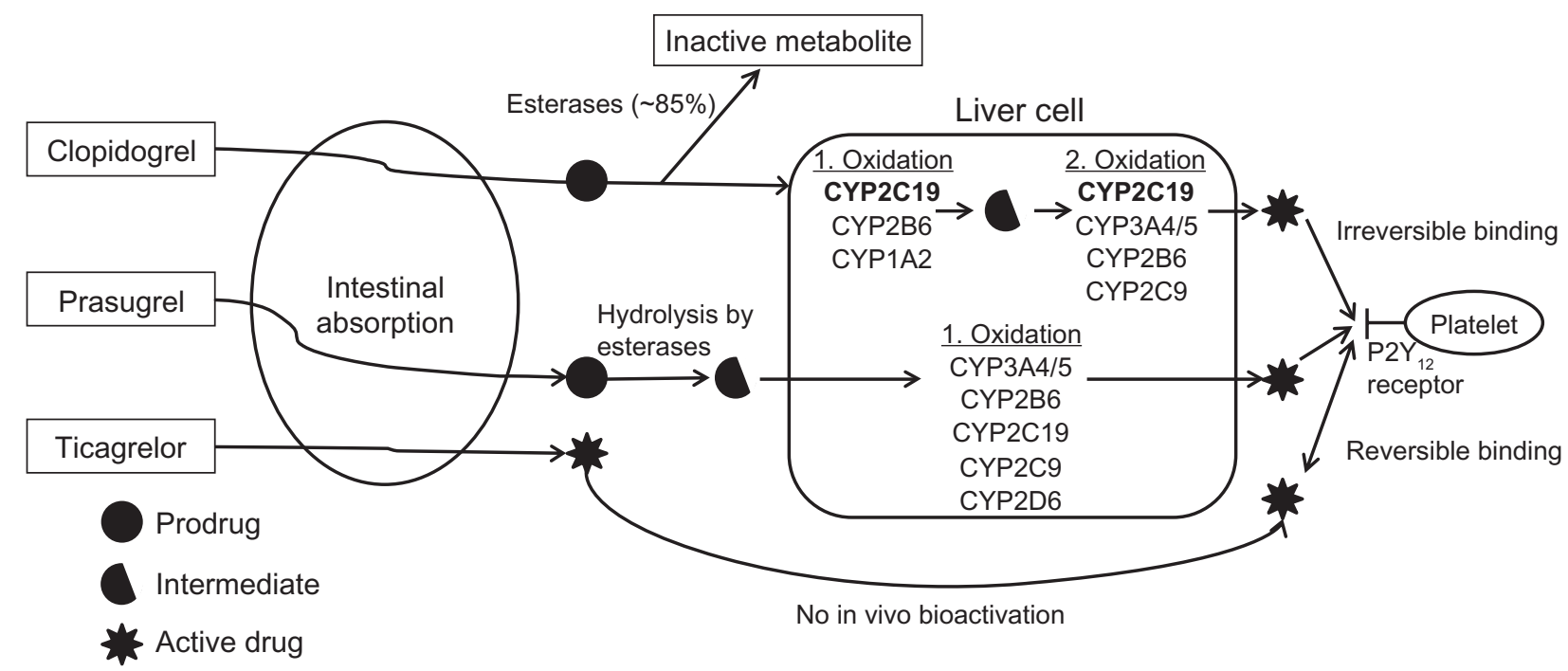

Figure I Bioactivation and mechanism of action of clopidogrel, prasugrel, and ticagrelor. CYP2CI9 (in bold) is the predominant enzyme in clopidogrel bioactivation. The $\mathrm{P} \mathrm{Y}_{12}$ receptor on the surface of the platelet is the site of action of clopidogrel, prasugrel, and ticagrelor.

genotype on clopidogrel efficacy in the setting of ACS or atrial fibrillation. ${ }^{78}$ However, there are two caveats with this substudy that are worth mentioning. First, fewer than $15 \%$ of patients with ACS underwent stent placement and none had ST segment elevation ACS. Secondly, the benefits of clopidogrel in the setting of atrial fibrillation are minimal. ${ }^{79}$ Thus, while these data suggest that reduced $C Y P 2 C 19$ activity does not impact clopidogrel efficacy in patients with lower-risk ACS who are predominately medically managed, an insufficient number of patients who underwent coronary revascularization were included to reach any conclusions in this higher-risk group.

There is some evidence suggesting an increased risk of bleeding with clopidogrel in ultrarapid metabolizers (UMs) with the CYP2C19*17 allele. Specifically, among over 1500 patients who underwent $\mathrm{PCI}$ and stent placement, carriers of a CYP 2 C19*17 allele had an increased risk for both major and minor bleeding with clopidogrel compared with noncarriers. ${ }^{58}$ The risk for bleeding was greatest among $* 17$ homozygotes, with an odds ratio of 3.27 (95\% confidence interval $1.33-8.10)$ compared with noncarriers of the $* 17$ allele.

The clopidogrel labeling was updated in March 2010 in response to reports of reduced efficacy with CYP2C19 lossof-function alleles. ${ }^{80}$ The label warns of reduced effectiveness in PMs and states that genetic testing for reduced-function CYP2C19 alleles is available. The label further advises health care professionals to consider alternative strategies in patients identified as PMs. However, the labeling falls short of providing recommendations on whom to genotype and what specific approaches to undertake in patients testing positive for a loss-of-function allele. Additionally, the labeling does not address IMs, who are clearly at increased risk for adverse cardiovascular events compared with EMs, although at lower risk than PMs.

Recently, the National Institutes of Health-supported Clinical Pharmacogenetics Implementation Consortium published guidelines on genotype-guided antiplatelet therapy in cardiovascular disease.$^{81}$ These guidelines do not make firm recommendations about which patients should be genotyped but instead suggest two potential approaches. The first approach is to genotype all patients with ACS or undergoing PCI; the second is to target moderate-to-high-risk patients, such as those with a history of stent thrombosis, diabetes, renal insufficiency, or high-risk coronary angiographic features. In patients who have CYP2C19 genotype data available, standard dose clopidogrel is recommended for EMs and UMs. Alternative therapy with prasugrel, ticagrelor, or cilostazol is recommended for IMs or PMs.

Similar to clopidogrel, prasugrel is a thienopyridine that irreversibly binds to the platelet $\mathrm{P} 2 \mathrm{Y}_{12}$ receptor and requires hepatic bioactivation (Figure 1). While CYP2C19 is involved in prasugrel bioactivation, CYP2C19 genotype does not affect the generation of active metabolite or drug efficacy, probably because the reaction is not highly dependent on CYP2C19. ${ }^{66,67,82,83}$ Ticagrelor is a recently approved reversible $\mathrm{P} 2 \mathrm{Y}_{12}$ antagonist that does not require hepatic bioactivation. As such, ticagrelor pharmacokinetics is not affected by $C Y P 2 C 19$ genotype. ${ }^{84}$ Cilostazol is a phosphodiesterase type III inhibitor shown to more effectively inhibit platelet aggregation than high-dose clopidogrel (eg, $150 \mathrm{mg} /$ day) in 
CYP2C19 IMs and PMs. ${ }^{85-87}$ Use of high-dose clopidogrel ( $150 \mathrm{mg}$ daily) is not recommended as an alternative therapy in PMs, based on recent data demonstrating no benefit with higher doses in patients with residual, ex vivo, platelet reactivity after PCI. ${ }^{81,88}$

\section{Impact of CYP2C19 genotype on the efficacy of PPIs} PPIs, including omeprazole, esomeprazole, pantoprazole, lansoprazole, and rabeprazole, are partially metabolized by CYP2C19. Loss-of-function CYP2C19 alleles result in higher plasma concentrations of PPIs and greater suppression of gastric acid. ${ }^{89-91}$ Consistent with these data, higher Helicobacter pylori eradication rates are achieved with both dual (PPI and amoxicillin) and triple (PPI, amoxicillin, and clarithromycin) therapy in patients with a defective CYP2C19 allele. Specifically, reported cure rates with standard dose omeprazole (20 mg/day) plus amoxicillin were 100\%, 60\%, and 29\%, in PMs, IMs, and EMs, respectively. ${ }^{92}$ Rabeprazole $10 \mathrm{mg}$ twice daily plus amoxicillin provided better $H$. pylori cure rates; although differences by genotype were observed (94\%, 92\% , and 61\% in PMs, IMs, and EMs, respectively). ${ }^{93}$ Using a higher dose of rabeprazole (10 $\mathrm{mg}$ four times daily) effectively eradicated $H$. pylori for EMs who failed initial therapy. ${ }^{93}$ Triple therapy that included omeprazole $20 \mathrm{mg}$ or lansoprazole $30 \mathrm{mg}$ twice daily produced cure rates of 98\%-100\% for PMs but only 73\%-86\% in EMs. ${ }^{94,95}$ Of EMs who failed triple therapy, a $97 \% H$. pylori eradication was achieved with high-dose lansoprazole (30 mg four times daily) and amoxicillin. ${ }^{94}$

CYP2C19 genotype also impacts the effectiveness of PPIs for gastroesophageal reflux disease. Among patients with gastroesophageal reflux disease treated with lansoprazole $30 \mathrm{mg}$ daily for 8 weeks, cure rates of mucosal breaks were $85 \%$ in PMs, $60 \%$ in IMs, and $46 \%$ in EMs. ${ }^{96}$ Those with the EM phenotype and the most erosive esophagitis achieved cure rates of only $17 \%$.

Similar to $C Y P 2 C 9$, there is evidence that $C Y P 2 C 19$ gene expression changes with development, with adult expression levels reached by age $10 .{ }^{35}$ As a consequence, the CYP2C19 genotype-PPI response relationship may differ between adult and pediatric patients. In support of this, a singledose pharmacokinetic study in children showed no effect of CYP2C19 genotype on omeprazole pharmacokinetics. ${ }^{97}$ In contrast, CYP2C19 genotype clearly impacts omeprazole levels in adults. ${ }^{91}$

Information regarding $C Y P 2 C 19$ genotype is included in the drug interaction and clinical pharmacology sections of rabeprazole and esomeprazole labels. ${ }^{1}$ The data suggest that use of higher PPI doses will overcome reduced effectiveness in EMs. ${ }^{93,94}$ Dosing strategies for PPIs based on CYP2C19 genotype have been proposed for rabeprazole: $20 \mathrm{mg} /$ day for PMs, $20 \mathrm{mg}$ twice daily for IMs, and $10 \mathrm{mg}$ four times daily for EMs. ${ }^{98}$

\section{Impact of CYP2CI 9 genotype on nelfinavir response} in human immunodeficiency virus (HIV)

Nelfinavir is metabolized by CYP2C19 to the hydroxyltertbutylamide (M8) metabolite. CYP2C19 genotype can influence the bioavailability of nelfinavir, with lower oral clearance with the $* 2$ allele. ${ }^{99}$ Saitoh et al ${ }^{99}$ examined the effect of CYP2C19 genotype on antiviral response to nelfinavir in 152 children taking highly active antiretroviral therapy. At 24 weeks, presence of the CYP2C19*2 allele was associated with a greater likelihood of achieving plasma HIV RNA < 400 copies/mL; 46\%, 69\%, and 63\% of patients with the $* 1 / * 1, * 1 / * 2$, and $* 2 / * 2$ genotypes, respectively, achieved concentrations $<400$ copies/mL. Others have reported a trend toward decreased virologic failure with the $C Y P 2 C 19 * 2$ allele. ${ }^{100}$ Information regarding CYP2C19 genotype is included in the drug interaction and clinical pharmacology sections of the nelfinavir label. However, no recommendations are provided regarding genetic testing.

\section{CYP2D6 genotype}

\section{Discussion of clinically relevant variants}

The CYP2D6 enzyme metabolizes about $25 \%$ of clinically used drugs from many different drug classes including antidepressants, antipsychotics, antihypertensives, and analgesics. Since early reports of a population exhibiting defective metabolism of debrisoquine or sparteine (CYP2D6 substrates) as a result of genotype, ${ }^{101,102}$ genetic polymorphisms leading to different CYP2D6 phenotypes have been extensively studied. Based on the extent of CYP2D6 substrate metabolism, the population is largely divided into four different groups, listed in order of decreasing CYP2D6 activity: UMs, EMs, IMs, and PMs. EMs carry at least one CYP2D6 allele showing normal enzyme function, IMs carry one CYP2D6 allele showing reduced function and another with no CYP2D6 function, and PMs carry two nonfunctional CYP2D6 alleles. ${ }^{103}$ UMs, however, carry multiple copies of functional CYP2D6 genes. ${ }^{104}$ The $C Y P 2 D 6 * 1, * 2$, and $* 4$ alleles are the most common alleles associated with the gene duplication and multiduplication. There are racial differences in the frequency of CYP2D6 alleles (Table 5). Ethiopian and Saudi Arabian populations have an unusually high $(10 \%-16 \%)$ frequency of 
Table 5 Major CYP2D6 variants

\begin{tabular}{|c|c|c|c|c|c|}
\hline \multirow[t]{2}{*}{ Allele } & \multirow[t]{2}{*}{ Gene mutation(s) } & \multirow{2}{*}{$\begin{array}{l}\text { Consequence of mutation } \\
\text { on CYP2D6 activity }\end{array}$} & \multicolumn{3}{|c|}{ Allele frequency (\%) } \\
\hline & & & Caucasian & African American & Asian \\
\hline CYP2D6*I & Wild type & Normal & $22-32$ & $29-36$ & $43-55$ \\
\hline CYP2D6*2 & R296C, S486T & Normal & 22 & $4-14$ & $0-2$ \\
\hline CYP2D $6 * 4$ & Splicing defect & Absent & $20-21$ & $2-8$ & 1 \\
\hline CYP2D6*5 & CYP2D6 deletion & Absent & $2-7$ & $4-6$ & 6 \\
\hline CYP2D6*10 & P34S, S486T & Decreased & $\mathrm{I}-2$ & $2-6$ & $38-70$ \\
\hline CYP2D6*17 & TI07I, R296C, S486T & Decreased & $0-1$ & $16-35$ & 0 \\
\hline CYP2D6*29 & VI36I, R296C, V338M, S486T & Decreased & $0-1$ & $5-8$ & NR \\
\hline CYP2D6*4I & - I584G $>$ C, splicing defect & Decreased & 8 & 2 & $0-2$ \\
\hline CYP2D6xn & Gene duplication or multiduplication & Increased & $\mathrm{I}-5$ & $2-5$ & $0-1$ \\
\hline
\end{tabular}

Note: Data from Bradford et al, ${ }^{103} \mathrm{Sim},{ }^{141} \mathrm{Cai}$ et al, ${ }^{142}$ and Sachse et al. ${ }^{143}$

Abbreviation: NR, not reported.

CYP2D6 gene duplication when compared with populations in other African or Asian countries, the cause of which has not been elucidated. ${ }^{105}$

\section{Impact of CYP2D6 genotype on response to opioid analgesics}

Codeine and tramadol are prodrugs requiring conversion via CYP2D6 to their therapeutically active metabolites, morphine and $O$-desmethyltramadol, respectively. Poor CYP2D6 metabolizers achieve lower metabolite concentrations and experience minimal analgesic relief with usual doses of these drugs. ${ }^{106-109}$ In contrast, patients with CYP2D6 gene duplication and the UM phenotype are at risk for toxic plasma concentrations of the morphine and $O$-desmethyltramadol metabolites after taking codeine or tramadol, respectively. ${ }^{110-112}$ Indeed, there are reports of severe respiratory depression and abdominal pain in patients treated with codeine-containing analgesics, who were subsequently found to have the UM phenotype. ${ }^{111,112}$ In addition, serious opioid-related toxicity and even death have been reported in breastfed infants of mothers with the UM phenotype. ${ }^{113}$ These data suggest that codeine- and tramadol-containing analgesics should be reserved for patients with the EM phenotype to avoid analgesic failure in PMs and toxicity in UMs.

\section{Impact of CYP2D6 genotype on response to antidepressants and antipsychotics}

The CYP2D6 enzyme is involved in the metabolism of secondary (eg, protriptyline, nortriptyline) and tertiary (eg, doxepine) tricyclic antidepressants. The PM phenotype has been correlated with greater tricyclic antidepressant plasma concentrations and lower dose requirements. ${ }^{114,115}$ In contrast, extremely low nortriptyline concentrations have been observed in patients with multiple CYP2D6 gene copies. ${ }^{116}$ Tricyclic antidepressant doses two to five times higher than normally recommended may be necessary to achieve therapeutic plasma concentrations in UMs. ${ }^{117,118}$ Pharmacogenetic information is included in the labeling of doxepine and protriptyline (Table 1). Lower doses of these drugs should be considered in patients with a reduced-function $C Y P 2 D 6$ allele. ${ }^{1}$

The CYP2D6 genotype has also been associated with plasma concentrations of various selective serotonin reuptake inhibitors (SSRIs), such as paroxetine and fluoxetine. ${ }^{119}$ For example, Charlier et al ${ }^{120}$ reported significantly higher steady-state plasma concentrations of paroxetine and fluoxetine among PMs compared with EMs. However, results from various pharmacokinetic studies are inconsistent, and there is no clear correlation between CYP2D6 genotype and clinical response. ${ }^{119}$ In a systematic review of 37 research articles, Thakur et al ${ }^{119}$ concluded that data are insufficient to support CYP2D6 genotyping to guide SSRI prescribing.

Evidence to support CYP2D6 genotyping to predict efficacy of antipsychotic therapy is also limited. ${ }^{121}$ However, there are data supporting an association between CYP2D6 polymorphisms and antipsychotic toxicity. The CYP2D6 enzyme extensively metabolizes the typical (eg, haloperidol, perphenazine, and thioridazine) and atypical (eg, risperidone, clozapine, and aripiprazole) antipsychotics. Higher plasma concentrations of antipsychotics, including perphenazine, haloperidol, thioridazine, and risperidone, are observed in individuals with reduced-function CYP2D6 alleles compared with EMs. ${ }^{122,123}$ In a meta-analysis of prospectively designed studies, Fleeman et al ${ }^{121}$ reported that antipsychotic-treated patients with a nonfunctional CYP2D6 allele were at higher risk for tardive dyskinesia (odds ratio of $1.83,95 \%$ confidence interval 1.09-3.08) and parkinsonism (odds ratio of $1.64,95 \%$ confidence interval 1.04-2.58) compared with EMs. ${ }^{121}$ However, the authors concluded that the differences observed by genotype were small and probably not of clinical significance. 
Pharmacogenetic information is included in the labeling of thioridazine, clozapine, and aripiprazole. The language is strongest for thioridazine, which has the potential to prolong the QT interval in a dose-dependent manner, thus increasing the risk for life-threatening ventricular arrhythmias. The CYP2D6 PM phenotype is correlated with greater QT interval prolongation during thioridazine therapy. ${ }^{124}$ As such, thioridazine is contraindicated in patients known to have reduced CYP2D6 activity. Recommendations for other antipsychotics are shown in Table 1.

\section{Impact of CYP2D6 genotype on response to $\beta$-blockers}

Beta-blockers are metabolized by CYP2D6, and CYP2D6 polymorphisms have significant effects on $\beta$-blocker plasma concentrations. ${ }^{125,126}$ However, data regarding the clinical significance of CYP2D6 genotype on $\beta$-blocker response are inconsistent. For example, Rau et $\mathrm{al}^{125}$ reported significantly higher metoprolol plasma concentrations in PMs versus EMs ( $70 \mathrm{ng} / \mathrm{mL}$ versus $14 \mathrm{ng} / \mathrm{mL}$ ), despite similar drug doses. This translated into greater reductions in heart rate and diastolic blood pressure in PMs. In contrast, Terra et $\mathrm{al}^{126}$ found that, while $S$-metoprolol plasma concentrations differed significantly by CYP2D6 genotype among heart failure patients, genotype had no effect on $\beta$-blocker tolerability, heart rate, or systolic blood pressure response. Beta-blockers have a wide therapeutic index and thus genes affecting drug disposition may have minimal effects on drug response. Genes for drug target proteins may be more likely to be of clinical significance for $\beta$-blockers and other drugs with a wide therapeutic index. Indeed, polymorphisms in the gene encoding for the $\beta_{1}$-adrenergic receptor are associated with clinical response to $\beta$-blockers in both hypertension and heart failure. ${ }^{127,128}$

\section{Impact of CYP2D6 genotype on outcomes with tamoxifen therapy}

Tamoxifen is widely prescribed for estrogen receptor-positive breast cancer. Tamoxifen requires biotransformation to its active 4-hydroxytamoxifen and endoxifen metabolites, which possess potent antiestrogenic effects. The CYP2D6 enzyme is a key enzyme in tamoxifen bioactivation. Tamoxifen metabolite levels are inversely correlated with the number of defective CYP2D6 alleles. ${ }^{129,130}$ The CYP2D6 genotype is estimated to explain $39 \%$ and $9 \%$ of the variability in endoxifen and 4- hydroxytamoxifen plasma concentrations, respectively. ${ }^{129}$

The ability to metabolize tamoxifen has been associated with treatment outcomes. ${ }^{131}$ In over 1300 patients with estrogen receptor-positive breast cancer, treatment with tamoxifen resulted in greater disease recurrence in patients with a reduced or loss-of-function $C Y P 2 D 6$ allele compared with those with normal enzyme activity. The highest recurrence rates occurred in patients with two loss-of-function $(* 3, * 4$, or $* 5$ ) alleles (PMs), who had a nearly twofold higher incidence of recurrence (29\% in PMs versus $14.9 \%$ in EMs). Similarly, patients with a reduced-function allele had worse event-free survival (hazard ratio $1.33,95 \%$ confidence interval 1.06-1.68) and disease-free survival (hazard ratio 1.29, 95\% confidence interval 1.03-1.61) than EMs. Other studies have shown similarly deleterious effects of $C Y P 2 D 6$ variant alleles on clinical outcomes with tamoxifen. ${ }^{132-134}$ However, the data are inconsistent and, in one case, conflicting. ${ }^{135,136}$ The discrepancies in the data may be secondary to factors other than CYP2D6 genotype influencing plasma concentrations of tamoxifen metabolites. ${ }^{130}$ While data exist to support genotype-guided adjuvant endocrine therapy, the clinical utility of such an approach is currently unclear. ${ }^{137,138}$

\section{Clinical relevance of $\mathbf{P 4 5 0}$ polymorphism}

The potential consequences of $P 450$ polymorphisms range from serious toxicity to ineffective drug therapy. Genetically determined reductions in P450 enzyme activity may have important implications for narrow-therapeutic-index drugs such as warfarin, where increased plasma concentrations contribute to drug toxicity. For prodrugs, such as codeine and clopidogrel, deficient enzyme activity can prevent the attainment of therapeutic drug plasma concentrations and lead to treatment failure. However, CYP2D6 gene duplication can lead to toxic reactions with codeine due to accumulation of the active morphine metabolite. For drugs with a wide therapeutic index, such as SSRIs and $\beta$-blockers, the clinical implications of $P 450$ gene variation are less significant.

To date, clinicians have been slow to embrace pharmacogenetics, despite the addition of pharmacogenetic information in the labeling for many drugs. Two notable exceptions include clopidogrel and opioid analgesics. Vanderbilt University Medical Center, Nashville, TN, recently announced efforts to genotype for CYP2C19 variants in all patients with a high likelihood of requiring potent antiplatelet therapy in the future. ${ }^{139}$ Genotype results are placed in the electronic medical record so that they may be used to assist in choosing appropriate antiplatelet therapy in the event of an ACS or PCI. Similarly, clinicians at St Jude Children's Research Hospital, Memphis, TN, test patients for CYP2D6 genotype to individualize analgesic therapy. ${ }^{140}$ 
Genotypes for the CYP2C9, CYP2C19, and CYP2D6 enzymes have minimal implications for disease susceptibility, as opposed to drug response. Specifically, an inherited deficiency in CYP2C9 may go completely undetected during an individual's lifetime unless that individual is prescribed a narrow therapeutic index drug, such as warfarin, that relies on CYP2C9 for metabolism. Similarly, a person with inactive CYP2D6 may suffer no untoward effects unless exposed to a drug such as thioridazine that can produce deleterious cardiac consequences in CYP2D6 PMs. Thus, P450 genotyping may pose less ethical concerns than genotyping for disease-associated variants. As such, $P 450$ genotyping is likely to lead the way in the clinical implementation of pharmacogenomics, as evidenced by current efforts at Vanderbilt University and St Jude Children's Hospital. Genotyping arrays that broadly detect variation in multiple $P 450$ genes are commercially available. Given the breadth of drugs that require P450 metabolism, use of such arrays may prove to be a feasible approach to broad implementation of P450 genotype-guided drug therapy.

\section{Acknowledgments}

This work was supported by the American Heart Association, Midwest Affiliate (10GRNT3750024) and National Institutes of Health, National Heart Lung and Blood Institute (HL106097).

\section{Disclosure}

Dr Cavallari is co-inventor of " $C Y P 2 C 9 * 8$ alleles correlate with decreased warfarin metabolism and increased warfarin sensitivity," US Utility Patent Application No 12/572,908, published May 27, 2010; Pub No US 2010/0130599. The authors declare no other conflicts of interest in this work.

\section{References}

1. US Food and Drug Administration. Table of pharmacogenomic biomarkers in drug labels [web page on the Internet]. Silver Spring, MD: US Food and Drug Administration; 2011 [updated September 27]. Available from: http://www.fda.gov/Drugs/ScienceResearch/ ResearchAreas/Pharmacogenetics/ucm083378.htm. Accessed September 29, 2011.

2. Mo SL, Zhou ZW, Yang LP, Wei MQ, Zhou SF. New insights into the structural features and functional relevance of human cytochrome P450 2C9. Part I. Curr Drug Metab. 2009;10(10):1075-1126.

3. Sim SC. CYP2CP allele nomenclature. Home page of the Human Cytochrome P450 (CYP) Allele Nomenclature Committee [website on the Internet]. Human Cytochrome P450 (CYP) Allele Nomenclature Committee; 2011 [updated May 2]. Available from: http://www. cypalleles.ki.se/cyp2c9.htm. Accessed September 28, 2011.

4. Gage BF, Eby C, Johnson JA, et al. Use of pharmacogenetic and clinical factors to predict the therapeutic dose of warfarin. Clin Pharmacol Ther. 2008;84(3):326-331.
5. Cavallari LH, Langaee TY, Momary KM, et al. Genetic and clinical predictors of warfarin dose requirements in African Americans. Clin Pharmacol Ther. 2010;87(4):459-464.

6. Takahashi H, Wilkinson GR, Nutescu EA, et al. Different contributions of polymorphisms in VKORC1 and CYP2C9 to intra- and interpopulation differences in maintenance dose of warfarin in Japanese, Caucasians and African-Americans. Pharmacogenet Genomics. 2006; 16(2):101-110.

7. Rettie AE, Wienkers LC, Gonzalez FJ, Trager WF, Korzekwa KR. Impaired (S)-warfarin metabolism catalysed by the R144C allelic variant of CYP2C9. Pharmacogenetics. 1994;4(1):39-42.

8. Lee CR, Goldstein JA, Pieper JA. Cytochrome P450 2C9 polymorphisms: a comprehensive review of the in-vitro and human data. Pharmacogenetics. 2002;12(3):251-263.

9. Sullivan-Klose TH, Ghanayem BI, Bell DA, et al. The role of the CYP2C9-Leu359 allelic variant in the tolbutamide polymorphism. Pharmacogenetics. 1996;6(4):341-349.

10. Wei L, Locuson CW, Tracy TS. Polymorphic variants of CYP2C9: mechanisms involved in reduced catalytic activity. Mol Pharmacol. 2007;72(5):1280-1288.

11. Dickmann LJ, Rettie AE, Kneller MB, et al. Identification and functional characterization of a new CYP2C9 variant (CYP2C9*5) expressed among African Americans. Mol Pharmacol. 2001;60(2): 382-387.

12. Allabi AC, Gala JL, Horsmans Y. CYP2C9, CYP2C19, ABCB1 (MDR1) genetic polymorphisms and phenytoin metabolism in a Black Beninese population. Pharmacogenet Genomics. 2005;15(11):779-786.

13. Blaisdell J, Jorge-Nebert LF, Coulter S, et al. Discovery of new potentially defective alleles of human CYP2C9. Pharmacogenetics. 2004;14(8):527-537.

14. Allabi AC, Gala JL, Horsmans Y, et al. Functional impact of CYP2C95, CYP2C96, CYP2C98, and CYP2C911 in vivo among black Africans. Clin Pharmacol Ther. 2004;76(2):113-118.

15. Takanashi K, Tainaka H, Kobayashi K, Yasumori T, Hosakawa M, Chiba K. CYP2C9 Ile359 and Leu359 variants: enzyme kinetic study with seven substrates. Pharmacogenetics. 2000;10(2):95-104.

16. Ansell J, Hirsh J, Hylek E, et al. Pharmacology and management of the vitamin K antagonists: American College of Chest Physicians EvidenceBased Clinical Practice Guidelines (8th Edition). Chest. 2008;133 (6 Suppl):S160-S198.

17. Hylek EM, Go AS, Chang Y, et al. Effect of intensity of oral anticoagulation on stroke severity and mortality in atrial fibrillation. $N$ Engl J Med. 2003;349(11):1019-1026.

18. Kearon C, Ginsberg JS, Kovacs MJ, et al. Comparison of low-intensity warfarin therapy with conventional-intensity warfarin therapy for longterm prevention of recurrent venous thromboembolism. N Engl J Med. 2003;349(7):631-639.

19. Hylek EM, Evans-Molina C, Shea C, Henault LE, Regan S. Major hemorrhage and tolerability of warfarin in the first year of therapy among elderly patients with atrial fibrillation. Circulation. 2007; 115(21):2689-2696.

20. Wadelius M, Chen LY, Lindh JD, et al. The largest prospective warfarin-treated cohort supports genetic forecasting. Blood. 2009; 113(4):784-792.

21. Scordo MG, Pengo V, Spina E, Dahl ML, Gusella M, Padrini R. Influence of CYP2C9 and CYP2C19 genetic polymorphisms on warfarin maintenance dose and metabolic clearance. Clin Pharmacol Ther. 2002;72(6):702-710.

22. Takahashi H, Kashima T, Nomizo Y, et al. Metabolism of warfarin enantiomers in Japanese patients with heart disease having different CYP2C9 and CYP2C19 genotypes. Clin Pharmacol Ther. 1998;63(5): 519-528.

23. Aithal GP, Day CP, Kesteven PJ, Daly AK. Association of polymorphisms in the cytochrome P450 CYP2C9 with warfarin dose requirement and risk of bleeding complications. Lancet. 1999;353(9154): 717-719. 
24. Higashi MK, Veenstra DL, Kondo LM, et al. Association between CYP2C9 genetic variants and anticoagulation-related outcomes during warfarin therapy. JAMA. 2002;287(13):1690-1698.

25. Limdi NA, Beasley TM, Crowley MR, et al. VKORC1 polymorphisms, haplotypes and haplotype groups on warfarin dose among AfricanAmericans and European-Americans. Pharmacogenomics. 2008;9(10): 1445-1458.

26. Margaglione M, Colaizzo D, D'Andrea G, et al. Genetic modulation of oral anticoagulation with warfarin. Thromb Haemost. 2000;84(5): 775-778.

27. Taube J, Halsall D, Baglin T. Influence of cytochrome P-450 CYP2C9 polymorphisms on warfarin sensitivity and risk of over-anticoagulation in patients on long-term treatment. Blood. 2000;96(5):1816-1819.

28. Klein TE, Altman RB, Eriksson N, et al. Estimation of the warfarin dose with clinical and pharmacogenetic data. $N$ Engl J Med. 2009; 360(8):753-764

29. Limdi NA, Wadelius M, Cavallari L, et al. Warfarin pharmacogenetics: a single VKORC1 polymorphism is predictive of dose across 3 racial groups. Blood. 2010;115(18):3827-3834.

30. Cooper GM, Johnson JA, Langaee TY, et al. A genome-wide scan for common genetic variants with a large influence on warfarin maintenance dose. Blood. 2008;112(4):1022-1027.

31. Takeuchi F, McGinnis R, Bourgeois S, et al. A genome-wide association study confirms VKORC1, CYP2C9, and CYP4F2 as principal genetic determinants of warfarin dose. PLoS Genet. 2009;5(3):e1000433. Epub March 20, 2009.

32. Perera MA, Gamazon E, Cavallari LH, et al. The missing association: sequencing-based discovery of novel SNPs in VKORC1 and CYP2C9 that affect warfarin dose in African Americans. Clin Pharmacol Ther. 2011;89(3):408-415.

33. Limdi NA, McGwin G, Goldstein JA, et al. Influence of CYP2C9 and VKORC1 1173C/T genotype on the risk of hemorrhagic complications in African-American and European-American patients on warfarin. Clin Pharmacol Ther. 2008;83(2):312-321.

34. Sanderson S, Emery J, Higgins J. CYP2C9 gene variants, drug dose, and bleeding risk in warfarin-treated patients: a HuGEnet systematic review and meta-analysis. Genet Med. 2005;7(2):97-104.

35. Koukouritaki SB, Manro JR, Marsh SA, et al. Developmental expression of human hepatic CYP2C9 and CYP2C19. J Pharmacol Exp Ther. 2004;308(3):965-974.

36. Nowak-Göttl U, Dietrich K, Schaffranek D, et al. In pediatric patients, age has more impact on dosing of vitamin $\mathrm{K}$ antagonists than VKORC1 or CYP2C9 genotypes. Blood. 2010;116(26):6101-6105.

37. Caraco Y, Blotnick S, Muszkat M. CYP2C9 genotype-guided warfarin prescribing enhances the efficacy and safety of anticoagulation: a prospective randomized controlled study. Clin Pharmacol Ther. 2008; 83(3):460-470.

38. Epstein RS, Moyer TP, Aubert RE, et al. Warfarin genotyping reduces hospitalization rates results from the MM-WES (Medco-Mayo Warfarin Effectiveness study). J Am Coll Cardiol. 2010;55(25): 2804-2812.

39. Huang SW, Chen HS, Wang XQ, et al. Validation of VKORC1 and CYP2C9 genotypes on interindividual warfarin maintenance dose: a prospective study in Chinese patients. Pharmacogenet Genomics. 2009; 19(3):226-234.

40. Anderson JL, Horne BD, Stevens SM, et al. Randomized trial of genotype-guided versus standard warfarin dosing in patients initiating oral anticoagulation. Circulation. 2007;116(22):2563-2570.

41. Burmester JK, Berg RL, Yale SH, et al. A randomized controlled trial of genotype-based Coumadin initiation. Genet Med. 2011;13(6): 509-518

42. French B, Joo J, Geller NL, et al. Statistical design of personalized medicine interventions: the Clarification of Optimal Anticoagulation through Genetics (COAG) trial. Trials. 2010;11:108.

43. Coumadin ${ }^{\circledR}$ (warfarin sodium) [package insert]. Princeton, NJ: BristolMyers Squibb; 2010.
44. Shin J, Cao D. Comparison of warfarin pharmacogenetic dosing algorithms in a racially diverse large cohort. Pharmacogenomics. 2011; 12(1):125-134.

45. Wu AH, Wang P, Smith A, et al. Dosing algorithm for warfarin using CYP2C9 and VKORC1 genotyping from a multi-ethnic population: comparison with other equations. Pharmacogenomics. 2008;9(2): $169-178$.

46. Sconce EA, Khan TI, Wynne HA, et al. The impact of CYP2C9 and VKORC1 genetic polymorphism and patient characteristics upon warfarin dose requirements: proposal for a new dosing regimen. Blood. 2005;106(7):2329-2333.

47. Küpfer A, Desmond PV, Schenker S. Family study of a genetically determined deficiency of mephenytoin hydroxylation in man [letter] Pharmacologist. 1979;21:173

48. Goldstein JA, Faletto MB, Romkes-Sparks M, et al. Evidence that CYP2C19 is the major (S)-mephenytoin $4^{\prime}$-hydroxylase in humans. Biochemistry. 1994;33(7):1743-1752.

49. Wedlund PJ, Aslanian WS, McAllister CB, Wilkinson GR, Branch RA. Mephenytoin hydroxylation deficiency in Caucasians: frequency of a new oxidative drug metabolism polymorphism. Clin Pharmacol Ther. 1984;36(6):773-780.

50. Küpfer A, Preisig R. Pharmacogenetics of mephenytoin: a new drug hydroxylation polymorphism in man. Eur J Clin Pharmacol. 1984; 26(6):753-759.

51. Sim SC. CYP2C9 allele nomenclature. Home page of the Human Cytochrome P450 (CYP) Allele Nomenclature Committee [website on the Internet]. Human Cytochrome P450 (CYP) Allele Nomenclature Committee; 2011 [updated May 2]. Available from: http://www. cypalleles.ki.se/cyp2c19.htm. Accessed September 29, 2011.

52. de Morais SM, Wilkinson GR, Blaisdell J, Nakamura K, Meyer UA, Goldstein JA. The major genetic defect responsible for the polymorphism of S-mephenytoin metabolism in humans. J Biol Chem. 1994; 269(22):15419-15422.

53. Goldstein JA, Ishizaki T, Chiba K, et al. Frequencies of the defective CYP2C19 alleles responsible for the mephenytoin poor metabolizer phenotype in various Oriental, Caucasian, Saudi Arabian and American black populations. Pharmacogenetics. 1997;7(1):59-64.

54. Wedlund PJ. The CYP2C19 enzyme polymorphism. Pharmacology. 2000;61(3):174-183.

55. Desta Z, Zhao X, Shin JG, Flockhart DA. Clinical significance of the cytochrome P450 2C19 genetic polymorphism. Clin Pharmacokinet. 2002;41(12):913-958.

56. Sim SC, Risinger C, Dahl ML, et al. A common novel CYP2C19 gene variant causes ultrarapid drug metabolism relevant for the drug response to proton pump inhibitors and antidepressants. Clin Pharmacol Ther. 2006;79(1):103-113.

57. Momary KM, Dorsch MP. Factors associated with clopidogrel nonresponsiveness. Future Cardiol. 2010;6(2):195-210.

58. Sibbing D, Koch W, Gebhard D, et al. Cytochrome 2C19*17 allelic variant, platelet aggregation, bleeding events, and stent thrombosis in clopidogrel-treated patients with coronary stent placement. Circulation. 2010;121(4):512-518.

59. Patrono C, Baigent C, Hirsh J, Roth G; American College of Chest Physicians. Antiplatelet drugs: American College of Chest Physicians Evidence-Based Clinical Practice Guidelines (8th Edition). Chest. 2008;133(6 Supp1):S199-S233.

60. Chen ZM, Jiang LX, Chen YP, et al. Addition of clopidogrel to aspirin in 45,852 patients with acute myocardial infarction: randomised placebocontrolled trial. Lancet. 2005;366(9497):1607-1621.

61. Yusuf S, Zhao F, Mehta SR, et al. Effects of clopidogrel in addition to aspirin in patients with acute coronary syndromes without ST-segment elevation. N Engl J Med. 2001;345(7):494-502.

62. Steinhubl SR, Berger PB, Mann JT 3rd, et al. Early and sustained dual oral antiplatelet therapy following percutaneous coronary intervention: a randomized controlled trial. JAMA. 2002;288(19): 2411-2420 
63. Combescure C, Fontana P, Mallouk N, et al. Clinical implications of clopidogrel non-response in cardiovascular patients: a systematic review and meta-analysis. J Thromb Haemost. 2010;8(5):923-933.

64. Bonello L, Tantry US, Marcucci R, et al. Consensus and future directions on the definition of high on-treatment platelet reactivity to adenosine diphosphate. J Am Coll Cardiol. 2010;56(12):919-933.

65. Umemura K, Furuta T, Kondo K. The common gene variants of CYP2C19 affect pharmacokinetics and pharmacodynamics in an active metabolite of clopidogrel in healthy subjects. J Thromb Haemost. 2008; 6(8):1439-1441.

66. Varenhorst C, James S, Erlinge D, et al. Genetic variation of CYP2C19 affects both pharmacokinetic and pharmacodynamic responses to clopidogrel but not prasugrel in aspirin-treated patients with coronary artery disease. Eur Heart J. 2009;30(14):1744-1752.

67. Brandt JT, Close SL, Iturria SJ, et al. Common polymorphisms of CYP2C19 and CYP2C9 affect the pharmacokinetic and pharmacodynamic response to clopidogrel but not prasugrel. JThromb Haemost. 2007;5(12):2429-2436.

68. Mega JL, Close SL, Wiviott SD, et al. Cytochrome p-450 polymorphisms and response to clopidogrel. $N$ Engl J Med. 2009;360(4): 354-362.

69. Trenk D, Hochholzer W, Fromm MF, et al. Cytochrome P450 2C19 $681 \mathrm{G}>\mathrm{A}$ polymorphism and high on-clopidogrel platelet reactivity associated with adverse 1-year clinical outcome of elective percutaneous coronary intervention with drug-eluting or bare-metal stents. J Am Coll Cardiol. 2008;51(20):1925-1934.

70. Collet JP, Hulot JS, Pena A, et al. Cytochrome P450 2C19 polymorphism in young patients treated with clopidogrel after myocardial infarction: a cohort study. Lancet. 2009;373(9660):309-317.

71. Giusti B, Gori AM, Marcucci R, et al. Relation of cytochrome P450 2C19 loss-of-function polymorphism to occurrence of drug-eluting coronary stent thrombosis. Am J Cardiol. 2009;103(6):806-811.

72. Shuldiner AR, O'Connell JR, Bliden KP, et al. Association of cytochrome $\mathrm{P} 450$ 2C19 genotype with the antiplatelet effect and clinical efficacy of clopidogrel therapy. JAMA. 2009;302(8):849-857.

73. Sibbing D, Stegherr J, Latz W, et al. Cytochrome P450 2C19 lossof-function polymorphism and stent thrombosis following percutaneous coronary intervention. Eur Heart J. 2009;30(8):916-922.

74. Simon T, Verstuyft C, Mary-Krause M, et al. Genetic determinants of response to clopidogrel and cardiovascular events. $N$ Engl J Med. 2009;360(4):363-375.

75. Harmsze AM, van Werkum JW, Ten Berg JM, et al. CYP2C19*2 and CYP2C9*3 alleles are associated with stent thrombosis: a case-control study. Eur Heart J. 2010;31(24):3046-3053.

76. Malek LA, Przyluski J, Spiewak M, et al. Cytochrome P450 2C19 polymorphism, suboptimal reperfusion and all-cause mortality in patients with acute myocardial infarction. Cardiology. 2010;117(2):81-87.

77. Mega JL, Simon T, Collet JP, et al. Reduced-function CYP2C19 genotype and risk of adverse clinical outcomes among patients treated with clopidogrel predominantly for PCI: a meta-analysis. JAMA. 2010; 304(26):1821-1830.

78. Paré G, Mehta SR, Yusuf S, et al. Effects of CYP2C19 genotype on outcomes of clopidogrel treatment. N Engl J Med. 2010;363(18): 1704-1714

79. Connolly SJ, Pogue J, Hart RG, et al. Effect of clopidogrel added to aspirin in patients with atrial fibrillation. $N$ Engl J Med. 2009;360: 2066-2078.

80. US Food and Drug Administration. FDA announces new boxed warning on Plavix: alerts patients, health care professionals to potential for reduced effectiveness [press release]. Silver Spring, MD: US Food and Drug Administration; 2010 [March 12]. Available from: http://www. fda.gov/NewsEvents/Newsroom/PressAnnouncements/ucm204253. htm. Accessed July 27, 2011.

81. Scott SA, Sangkuhl K, Gardner EE, et al. Clinical Pharmacogenetics Implementation Consortium Guidelines for Cytochrome P450-452C19 (CYP2C19) Genotype and Clopidogrel Therapy. Clin Pharmacol Ther. 2011;90(2):328-332.
82. Mega JL, Close SL, Wiviott SD, et al. Cytochrome P450 genetic polymorphisms and the response to prasugrel: relationship to pharmacokinetic, pharmacodynamic, and clinical outcomes. Circulation. 2009;119(19):2553-2560.

83. Kelly RP, Close SL, Farid NA, et al. Pharmacokinetics and Pharmacodynamics Following Maintenance Doses of Prasugrel and Clopidogrel in Chinese Carriers of CYP2C19 Variants. Br J Clin Pharmacol. 2011; doi:10.1111/j.1365-2125.2011.04049.x. [Epub ahead of print.]

84. Wallentin L, James S, Storey RF, et al. Effect of CYP2C19 and ABCB1 single nucleotide polymorphisms on outcomes of treatment with ticagrelor versus clopidogrel for acute coronary syndromes: a genetic substudy of the PLATO trial. Lancet. 2010;376(9749): $1320-1328$.

85. Kim IS, Jeong YH, Park Y, et al. Platelet Inhibition by Adjunctive Cilostazol Versus High Maintenance-Dose Clopidogrel in Patients With Acute Myocardial Infarction According to Cytochrome P450 2C19 Genotype. JACC Cardiovasc Interv. 2011;4(4):381-391.

86. Hwang SJ, Jeong YH, Kim IS, et al. Cytochrome 2C19 polymorphism and response to adjunctive cilostazol versus high maintenance-dose clopidogrel in patients undergoing percutaneous coronary intervention. Circ Cardiovasc Interv. 2010;3(5):450-459.

87. Park KW, Park JJ, Lee SP, et al. Cilostazol attenuates on-treatment platelet reactivity in patients with CYP2C19 loss of function alleles receiving dual antiplatelet therapy: a genetic substudy of the CILON-T randomised controlled trial. Heart. 2011;97(8):641-647.

88. Price MJ, Berger PB, Teirstein PS, et al. Standard- vs high-dose clopidogrel based on platelet function testing after percutaneous coronary intervention: the GRAVITAS randomized trial. JAMA. 2011; 305(11):1097-1105.

89. Saitoh T, Fukushima Y, Otsuka H, et al. Effects of rabeprazole, lansoprazole and omeprazole on intragastric $\mathrm{pH}$ in CYP2C19 extensive metabolizers. Aliment Pharmacol Ther. 2002;16(10):1811-1817.

90. Shirai N, Furuta T, Xiao F, et al. Comparison of lansoprazole and famotidine for gastric acid inhibition during the daytime and night-time in different CYP2C19 genotype groups. Aliment Pharmacol Ther. 2002; 16(4):837-846.

91. Shirai N, Furuta T, Moriyama Y, et al. Effects of CYP2C19 genotypic differences in the metabolism of omeprazole and rabeprazole on intragastric pH. Aliment Pharmacol Ther. 2001;15(12): 1929-1937.

92. Furuta T, Ohashi K, Kamata T, et al. Effect of genetic differences in omeprazole metabolism on cure rates for Helicobacter pylori infection and peptic ulcer. Ann Intern Med. 1998;129(12):1027-1030.

93. Furuta T, Shirai N, Takashima M, et al. Effects of genotypic differences in CYP2C19 status on cure rates for Helicobacter pylori infection by dual therapy with rabeprazole plus amoxicillin. Pharmacogenetics. 2001;11(4):341-348

94. Furuta T, Shirai N, Takashima M, et al. Effect of genotypic differences in CYP2C19 on cure rates for Helicobacter pylori infection by triple therapy with a proton pump inhibitor, amoxicillin, and clarithromycin. Clin Pharmacol Ther. 2001;69(3):158-168

95. Tanigawara Y, Aoyama N, Kita T, et al. CYP2C19 genotype-related efficacy of omeprazole for the treatment of infection caused by Helicobacter pylori. Clin Pharmacol Ther. 1999;66(5):528-534.

96. Furuta T, Shirai N, Watanabe F, et al. Effect of cytochrome P4502C19 genotypic differences on cure rates for gastroesophageal reflux disease by lansoprazole. Clin Pharmacol Ther. 2002;72(4): 453-460.

97. Kearns GL, Leeder JS, Gaedigk A. Impact of the CYP2C19*17 allele on the pharmacokinetics of omeprazole and pantoprazole in children: evidence for a differential effect. Drug Metab Dispos. 2010; 38(6):894-897.

98. Sugimoto M, Furuta T, Shirai N, et al. Different dosage regimens of rabeprazole for nocturnal gastric acid inhibition in relation to cytochrome P450 2C19 genotype status. Clin Pharmacol Ther. 2004; 76(4):290-301. 
99. Saitoh A, Capparelli E, Aweeka F, et al. CYP2C19 genetic variants affect nelfinavir pharmacokinetics and virologic response in HIV1-infected children receiving highly active antiretroviral therapy. J Acquir Immune Defic Syndr. 2010;54(3):285-289.

100. Haas DW, Smeaton LM, Shafer RW, et al. Pharmacogenetics of longterm responses to antiretroviral regimens containing Efavirenz and or Nelfinavir: an Adult Aids Clinical Trials Group Study. J Infect Dis. 2005;192(11):1931-1942.

101. Mahgoub A, Idle JR, Dring LG, Lancaster R, Smith RL. Polymorphic hydroxylation of Debrisoquine in man. Lancet. 1977;2(8038): 584-586.

102. Eichelbaum M, Spannbrucker N, Steincke B, Dengler HJ. Defective $\mathrm{N}$-oxidation of sparteine in man: a new pharmacogenetic defect. Eur J Clin Pharmacol. 1979;16(3):183-187.

103. Bradford LD. CYP2D6 allele frequency in European Caucasians, Asians, Africans and their descendants. Pharmacogenomics. 2002;3(2):229-243

104. Johansson I, Lundqvist E, Bertilsson L, Dahl ML, Sjöqvist F, IngelmanSundberg M. Inherited amplification of an active gene in the cytochrome P450 CYP2D locus as a cause of ultrarapid metabolism of debrisoquine. Proc Natl Acad Sci U SA. 1993;90(24):11825-11829.

105. Ingelman-Sundberg M. Genetic polymorphisms of cytochrome P450 2D6 (CYP2D6): clinical consequences, evolutionary aspects and functional diversity. Pharmacogenomics $J$. 2005;5(1):6-13.

106. Eckhardt K, Li S, Ammon S, et al. Same incidence of adverse drug events after codeine administration irrespective of the genetically determined differences in morphine formation. Pain. 1998; 76(1-2):27-33.

107. Sindrup SH, Brøsen K, Bjerring P, et al. Codeine increases pain thresholds to copper vapor laser stimuli in extensive but not poor metabolizers of sparteine. Clin Pharmacol Ther. 1990;48(6):686-693.

108. Stamer UM, Lehnen K, Höthker F, et al. Impact of CYP2D6 genotype on postoperative tramadol analgesia. Pain. 2003;105(1-2):231-238.

109. Wang G, Zhang H, He F, Fang X. Effect of the CYP2D6*10 C188T polymorphism on postoperative tramadol analgesia in a Chinese population. Eur J Clin Pharmacol. 2006;62(11):927-931.

110. Kirchheiner J, Keulen JT, Bauer S, Roots I, Brockmöller J. Effects of the CYP2D6 gene duplication on the pharmacokinetics and pharmacodynamics of tramadol. J Clin Psychopharmacol. 2008;28(1): 78-83.

111. Gasche Y, Daali Y, Fathi M, et al. Codeine intoxication associated with ultrarapid CYP2D6 metabolism. $N$ Engl J Med. 2004;351(27): 2827-2831.

112. Dalén P, Frengell C, Dahl ML, Sjöqvist F. Quick onset of severe abdominal pain after codeine in an ultrarapid metabolizer of debrisoquine. Ther Drug Monit. 1997;19(5):543-544.

113. Madadi P, Ross CJ, Hayden MR, et al. Pharmacogenetics of neonatal opioid toxicity following maternal use of codeine during breastfeeding: a case-control study. Clin Pharmacol Ther. 2009;85(1):31-35.

114. Kwadijk-de Gijsel S, Bijl MJ, Visser LE, et al. Variation in the CYP2D6 gene is associated with a lower serum sodium concentration in patients on antidepressants. Br J Clin Pharmacol. 2009;68(2): 221-225.

115. Bijl MJ, Visser LE, Hofman A, et al. Influence of the CYP2D6*4 polymorphism on dose, switching and discontinuation of antidepressants. Br J Clin Pharmacol. 2008;65(4):558-564.

116. Lee SY, Sohn KM, Ryu JY,Yoon YR, Shin JG, Kim JW. Sequencebased CYP2D6 genotyping in the Korean population. Ther Drug Monit. 2006;28(3):382-387.

117. Bertilsson L, Aberg-Wistedt A, Gustafsson LL, Nordin C. Extremely rapid hydroxylation of debrisoquine: a case report with implication for treatment with nortriptyline and other tricyclic antidepressants. Ther Drug Monit. 1985;7(4):478-480.

118. Bertilsson L, Dahl ML, Sjöqvist F, et al. Molecular basis for rational megaprescribing in ultrarapid hydroxylators of debrisoquine. Lancet. 1993;341(8836):63.
119. Thakur M, Grossman I, McCrory DC, et al. Review of evidence for genetic testing for CYP450 polymorphisms in management of patients with nonpsychotic depression with selective serotonin reuptake inhibitors. Genet Med. 2007;9(12):826-835.

120. Charlier C, Broly F, Lhermitte M, Pinto E, Ansseau M, Plomteux G. Polymorphisms in the CYP2D6 gene: association with plasma concentrations of fluoxetine and paroxetine. Ther Drug Monit. 2003; 25(6):738-742.

121. Fleeman N, DundarY, Dickson R, et al. Cytochrome P450 testing for prescribing antipsychotics in adults with schizophrenia: systematic review and meta-analyses. Pharmacogenomics J. 2010;11(1): $1-14$.

122. Dahl ML. Cytochrome p450 phenotyping/genotyping in patients receiving antipsychotics: useful aid to prescribing? Clin Pharmacokinet. 2002;41(7):453-470.

123. Suzuki T, Mihara K, Nakamura A, et al. Effects of the CYP2D6*10 allele on the steady-state plasma concentrations of aripiprazole and its active metabolite, dehydroaripiprazole, in Japanese patients with schizophrenia. Ther Drug Monit. 2011;33(1):21-24.

124. Llerena A, Berecz R, de la Rubia A, Dorado P. QTc interval lengthening is related to CYP2D6 hydroxylation capacity and plasma concentration of thioridazine in patients. $J$ Psychopharmacol. 2002; 16(4):361-364.

125. Rau T, Wuttke H, Michels LM, et al. Impact of the CYP2D6 genotype on the clinical effects of metoprolol: a prospective longitudinal study. Clin Pharmacol Ther. 2009;85(3):269-272.

126. Terra SG, Pauly DF, Lee CR, et al. beta-Adrenergic receptor polymorphisms and responses during titration of metoprolol controlled release/extended release in heart failure. Clin Pharmacol Ther. 2005; 77(3):127-137.

127. Johnson JA, Zineh I, Puckett BJ, McGorray SP, Yarandi HN, Pauly DF. Beta 1-adrenergic receptor polymorphisms and antihypertensive response to metoprolol. Clin Pharmacol Ther. 2003;74(1): $44-52$.

128. Terra SG, Hamilton KK, Pauly DF, et al. Beta1-adrenergic receptor polymorphisms and left ventricular remodeling changes in response to beta-blocker therapy. Pharmacogenet Genomics. 2005;15(4): 227-234.

129. Mürdter TE, Schroth W, Bacchus-Gerybadze L, et al. Activity levels of tamoxifen metabolites at the estrogen receptor and the impact of genetic polymorphisms of phase I and II enzymes on their concentration levels in plasma. Clin Pharmacol Ther. 2011;89(5):708-717.

130. Madlensky L, Natarajan L, Tchu S, et al. Tamoxifen metabolite concentrations, CYP2D6 genotype, and breast cancer outcomes. Clin Pharmacol Ther. 2011;89(5):718-725.

131. Schroth W, Hamann U, Fasching PA, et al. CYP2D6 polymorphisms as predictors of outcome in breast cancer patients treated with tamoxifen: expanded polymorphism coverage improves risk stratification. Clin Cancer Res. 2010;16(17):4468-4477.

132. Goetz MP, Knox SK, Suman VJ, et al. The impact of cytochrome P4502D6 metabolism in women receiving adjuvant tamoxifen. Breast Cancer Res Treat. 2007;101(1):113-121.

133. Schroth W, Antoniadou L, Fritz P, et al. Breast cancer treatment outcome with adjuvant tamoxifen relative to patient CYP2D6 and CYP2C19 genotypes. J Clin Oncol. 2007;25(33):5187-5193.

134. Lim HS, Ju Lee H, Seok Lee K, Sook Lee E, Jang IJ, Ro J. Clinical implications of CYP2D6 genotypes predictive of tamoxifen pharmacokinetics in metastatic breast cancer. J Clin Oncol. 2007;25(25): 3837-3845.

135. Nowell SA, Ahn J, Rae JM, et al. Association of genetic variation in tamoxifen-metabolizing enzymes with overall survival and recurrence of disease in breast cancer patients. Breast Cancer Res Treat. 2005; 91(3):249-258.

136. Wegman P, Vainikka L, Stål O, et al. Genotype of metabolic enzymes and the benefit of tamoxifen in postmenopausal breast cancer patients. Breast Cancer Res. 2005;7(3):R284-R290. 
137. Lash TL, Lien EA, Sørensen HT, Hamilton-Dutoit S. Genotypeguided tamoxifen therapy: time to pause for reflection? Lancet Oncol. 2009;10(8):825-833.

138. Yu KD, Huang AJ, Shao ZM. Tailoring adjuvant endocrine therapy for postmenopausal breast cancer: a CYP2D6 multiple-genotype-based modeling analysis and validation. PLoS One. 2010;5(12):e15649.

139. Hughes $\mathrm{S}$. Vanderbilt now also routinely gene testing for clopidogrel metabolizer status. TheHeart.Org [website on the Internet]. Montreal: TheHeart.Org; 2010. Available from: http://www.theheart.org/ article/1139495.do. Accessed August 11, 2011.

140. Relling MV, Altman RB, Goetz MP, Evans WE. Clinical implementation of pharmacogenomics: overcoming genetic exceptionalism. Lancet Oncol. 2010;11(6):507-509.
141. Sim SC. CYP2D6 allele nomenclature. Home page of the Human Cytochrome P450 (CYP) Allele Nomenclature Committee [website on the Internet]. Human Cytochrome P450 (CYP) Allele Nomenclature Committee; 2011 [updated September 16]. Available from: http://www. cypalleles.ki.se/cyp2d6.htm. Accessed September 29, 2011.

142. Cai WM, Nikoloff DM, Pan RM, et al. CYP2D6 genetic variation in healthy adults and psychiatric African-American subjects: implications for clinical practice and genetic testing. Pharmacogenomics $J$. 2006;(6):343-350.

143. Sachse C, Brockmoller J, Bauer S, Roots I. Cytochrome P450 2D6 variants in a Caucasian population: allele frequencies and phenotypic consequences. Am J Hum Genet. 1997;(60):284-295.

\section{Publish your work in this journal}

Pharmacogenomics and Personalized Medicine is an international, peerreviewed, open access journal characterizing the influence of genotype on pharmacology leading to the development of personalized treatment programs and individualized drug selection for improved safety, efficacy and sustainability. This journal is indexed on the American Chemical
Society's Chemical Abstracts Service (CAS). The manuscript management system is completely online and includes a very quick and fair peer-review system, which is all easy to use. Visit http://www.dovepress. $\mathrm{com} /$ testimonials.php to read real quotes from published authors.

Submit your manuscript here: http://www.dovepress.com/pharmacogenomics-and-personalized-medicine-journal 